\title{
Climate-smart crop production in semi-arid areas through increased knowledge of varieties, environment and management factors
}

\author{
C. Murungweni (iD) M. T. Van Wijk • \\ E. M. A. Smaling $\cdot$ K. E. Giller
}

Received: 6 January 2015/Accepted: 25 April 2015/Published online: 13 May 2015

(C) The Author(s) 2015. This article is published with open access at Springerlink.com

\begin{abstract}
In large regions of sub-Saharan Africa, semi-arid conditions are likely to increase with climate change, yet these regions are becoming more important to feed production zones due to increasing population pressure. A production system in the semi-arid south eastern Zimbabwe was studied to assess different possible growth conditions of food crop in relation to seasonal differences, spatial rainfall distribution, use of organic nutrients and different position in the landscape. The growth and yield of four crops (maize, sorghum, millet and groundnut) were assessed with or without manure during two seasons (2008/2009 and 2009/2010) in different landscape positions. Daily rainfall, soil and manure nutrient
\end{abstract}

C. Murungweni $(\bowtie) \cdot$ M. T. Van Wijk · K. E. Giller Plant Production Systems, Wageningen University, P.O. Box 430, 6700 AK Wageningen, The Netherlands e-mail: Chrispen.Murungweni@gmail.com

\section{Murungweni}

Department of Animal Production and Technology,

School of Agricultural Sciences and Technology,

Chinhoyi University of Technology,

P. Bag 7724, Chinhoyi, Zimbabwe

M. T. Van Wijk

Livestock Systems and the Environment, International Livestock Research Institute (ILRI), Nairobi, Kenya

E. M. A. Smaling

Faculty of Geo-information Science and Earth

Observation (ITC), University of Twente, P.O. Box 6,

7500 AA Enschede, The Netherlands levels, seed germination, crop establishment, grain yield and above-ground residue biomass were measured. Most important determining factors of crop yield were landscape position and the different within season rainfall distribution of the two seasons. Manure increased yield of sorghum grown in upland and maize grown in lower lowlands. Millet was affected by Quelea quelea birds, the reason why it is unpopular in south eastern Zimbabwe. Best-fit strategies can double total yield from 1.67 to $3.29 \mathrm{t} / \mathrm{ha}$ from the average 5.1 ha that farmers usually crop in south east Zimbabwe. Farmers in semi-arid areas can reduce risk of total crop failure by making a clever use of both the low lying and the upland areas depending on crops of their interest.

Keywords Cropping $\cdot$ Risk $\cdot$ Drought $\cdot$ Landscape position · Manure

\section{Introduction}

Some 260 million people live in the drought-prone semi-arid areas of sub-Saharan Africa (UNDP/UNSO 1997). The semi-arid areas are sandwiched between the Sahara Desert and the moist Guinea savanna in the north and the Kalahari Desert and the Miombo savannah in the south (UNEP 2010). Annual total rainfall ranges between 200 and $600 \mathrm{~mm}$ with potential evapotranspiration of 5-8 mm/day (Noy-Meir 
1973; Rockstrom 2000). Pastoral and agro-pastoral millet/sorghum systems prevail (Dixon et al. 2001). Semi-arid areas are characterised by low rainfall with high spatial and temporal variability leading to risk of severe drought (Snyder and Tartowski 2006). In the 1991-1992 drought in southern Africa a massive loss of cattle occurred (Batisani and Yarnal 2010; Eldridge 2002). Farmers in these areas give priority to reduce risks and buffer themselves from adverse weather conditions and droughts (Cooper et al. 2008).

The border zone between Mozambique, Zimbabwe and South Africa exhibits highly variable rainfall (Fig. 1) and is representative of the semi-arid regions of southern Africa. The local people in this region aspire to access cropping fields in different landscape positions (upland rain fed land and flood plains). This provides farmers with more options to deal with droughts and floods. The focus of our study is the rural area bordering the southern part of Gonarezhou National Park (Fig. 2), inhabited by 6400 households
(CSO 2002). Households in this region belong to the general livelihood types crop-based (41\%), non-farm based $(47 \%)$ and cattle-based $(12 \%)$ as locally defined (Murungweni et al. 2014). Whereas all households have access to uplands in the range of 4-10 ha per household, only $40 \%$ of the households have access to wetlands (Murungweni et al. 2014).

In sub-Saharan Africa, maize production is expanding into areas that were typically considered only suitable for production of sorghum and millet (Dixon et al. 2001). This is also the case in the study area. The Shangaan speaking people, the dominant people in the south-east Zimbabwe traditionally grew sorghum. Increased settlement of Shona-speaking people in this region increased the growing of maize which has been adopted by the Shangaan. Manure is not used in arable fields; local people believe that their soils are rich in nutrients (because the soils are mostly deep-black loamy to clay Eutric vertisols). In terms of livestock numbers, south-eastern Zimbabwe lies in the District
Fig. 1 Long-term annual rainfall $(\mathrm{mm})$ recorded at the two meteorological (Met) stations closest to the study area: a Beitbridge $\left(30.0^{\circ} \mathrm{E}\right.$, $\left.22.2^{\circ} \mathrm{S}\right)$ and $\mathbf{b}$ Buffalo Range $\left(31.6^{\circ} \mathrm{E}, 21.0^{\circ} \mathrm{S}\right)$. The shaded area on each graph 1 SD around the annual mean rainfall

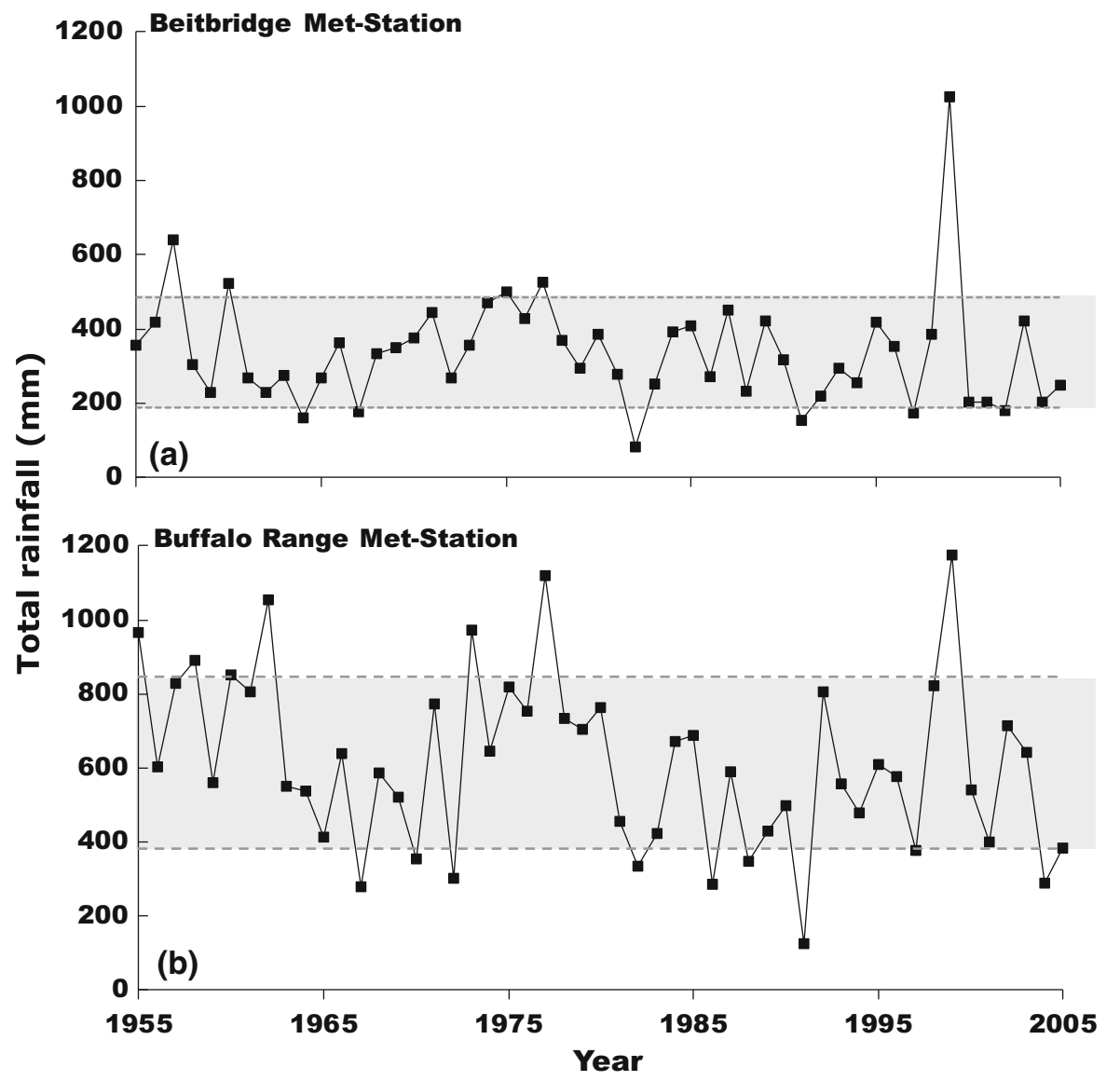




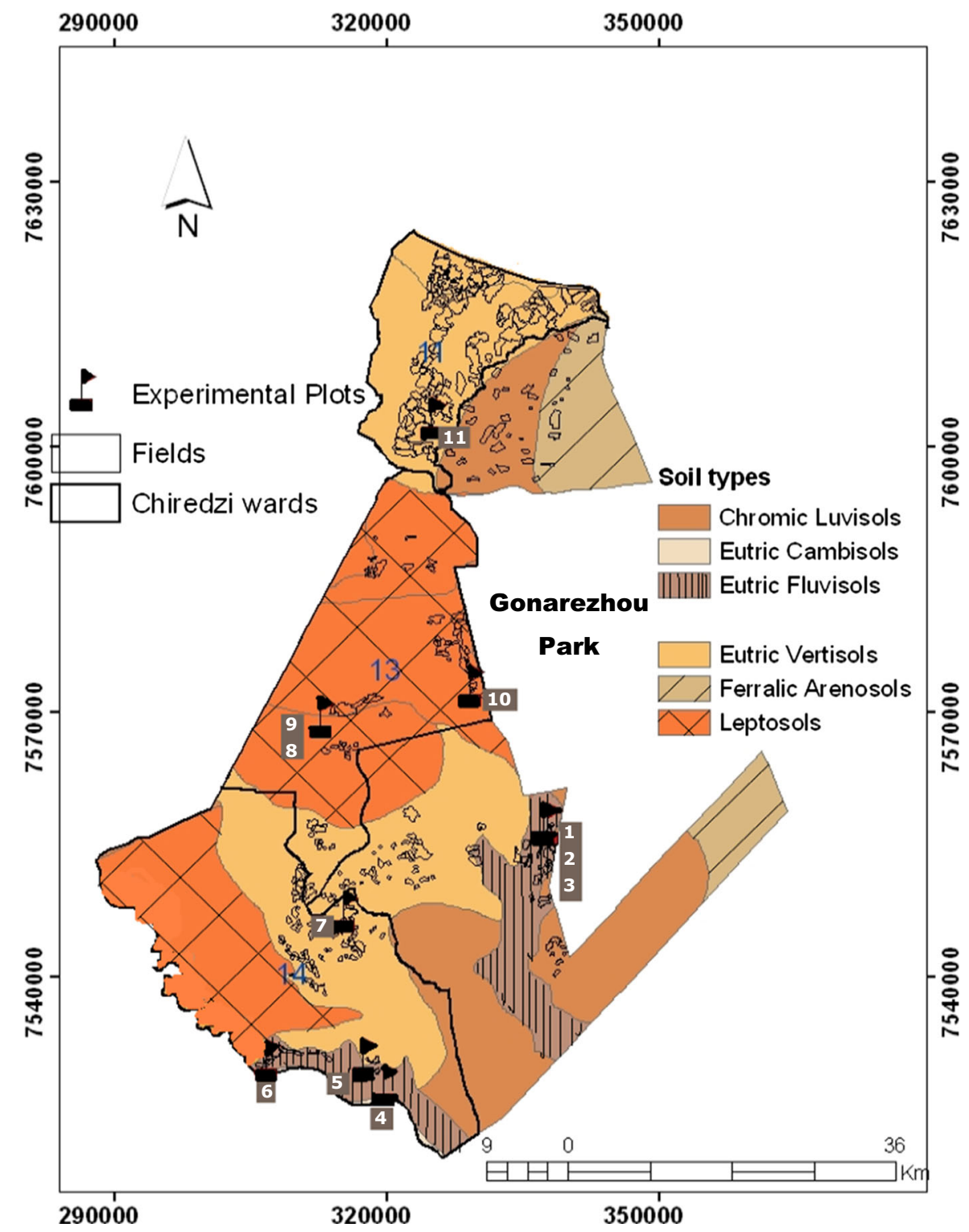

Fig. 2 Distribution of all of the cropping fields in Wards 11-15 during the 2006/2007 season adjacent to Gonarezhou National Park, south-east lowveld, Zimbabwe. The flags mark the

with the largest number of cattle in Zimbabwe. According to a survey by Murungweni (2011), cropbased households own between 10 and 20 cattle, whereas 12 percent of the farmers are of the cattlebased livelihood type owning between 30 and 80 cattle heads. According to same survey, $62 \%$ (or 1626 cropbased households) have access to the flood-plains with on average 1.1 ha per household.

Development programs in hot semi-arid regions often focus on nature conservation, ecotourism, and locations of the experimental plots and boxed numbers indicate the number of the experimental plot

wildlife habitat extension. However, food production remains important since the population continue to increase yet aridity is expected to increase due to climate change. The study area falls within the Great Limpopo Transfrontier Conservation Area, which is one of the 14 Transfrontier Conservation Areas (TFCAs) being established in southern Africa (Cumming et al. 2007; Spenceley 2008). For those living in the study area, establishment of TFCAs presents a new hazard, because the livelihood 
options proposed (most importantly ecotourism) are not directly under the control of local people (Dzingirai 2003).

One option to improve household food security of local people is to enhance food production. This can be done by growing a variety of crops, by using more drought-tolerant varieties, and by better exploiting landscape variability. Improved collection and use of manure is a further option. Mineral fertilizers are not used by local farmers who believe that their soils are fertile and addition of fertilizer exacerbates heat effects on their crops. Previous attempts by development organizations to increase the use of mineral fertilizer were unsuccessful, and in this study we focus on the use of manure. Spatial variation in rainfall (Fig. 1), different crop varieties, landscape positions and soil types (Fig. 2) combine to form a mosaic of crop growth conditions from which best-fit strategies could emerge (Giller et al. 2011). The objective of this study was to analyse and quantify these different growing conditions and identify those that provide greater yield and less risk of total crop failure. We propose simple decision rules based on specific responses to the environmental conditions, which give the farmers flexibility to respond to and cope with rainfall variability (Debaeke and Aboudrare 2004).

\section{Materials and methods}

The production potential of different crops and crop varieties (of short to long duration) across different landscape positions was investigated across two seasons. Sorghum (Sorghum bicolor [L.] Moench), pearl millet (Pennisetum glaucum [L.] R. Br.), maize (Zea mays L.) and groundnut (Arachis hypogaea L.) were the crops evaluated, with or without addition of manure. Combinations of crop, crop variety, manure and landscape position resulting in the greatest yield across years (good year/bad year), were considered to be 'best-fit' options. The best-fit options were used to evaluate implications of our crop experiments for household food self-sufficiency.

Site characteristics

The study area is located in the south eastern Zimbabwe (latitude $21^{\circ} 55^{\prime} \mathrm{S}$ and longitude $31^{\circ} 29^{\prime} \mathrm{E}$ ).
Minimum temperatures range between 4.3 and $21.1^{\circ} \mathrm{C}$ and maximum temperatures between 27.8 and $37.3{ }^{\circ} \mathrm{C}$. Some $40 \%$ of the soils in the area are Eutric Vertisols, $29 \%$ are Leptosols, $17 \%$ are Chromic Luvisols, $7 \%$ are Eutric Fluvisols and $7 \%$ are Ferralic Arenosols (FAO/UNESCO soil map of Zimbabwe). The boundaries of crop fields were delineated using a GPS (GPSmap 60CSx Garmin) and overlaid on a digitised image (2007) of all cropped fields using ArcView 3.1 (Fig. 2). Total annual rainfall measured at the two closest meteorological stations, Buffalo Range located $100 \mathrm{~km}$ NE of the study area, and Beitbridge located close to Limpopo river, $120 \mathrm{~km}$ to the west of the study area, show a large inter-annual variability, with intermittent severe droughts (Fig. 1). Rain gauges were installed at individual farmers' fields to record rain at each experimental field.

Farmers described the three important landscape positions used as the lower lowlands, upper lowlands and uplands. The lower lowlands lie within the floodplains and receive water from rainfall, run-on and flooding by rivers. The upper lowlands receive water from rainfall and run-on from adjacent uplands but are not flooded by the rivers. These upper lowland areas are also known in southern Africa as 'vleis', lowlying water retaining depressions that remain moist for longer periods into the dry season compared with the surrounding uplands. The upland areas are only rain fed.

\section{Experimental design}

Eleven fields of farmers of the crop-based livelihood type were selected from the three identified landscape positions within a $100 \mathrm{~km}$ radius for the crop experiments. Farmers of the crop-based livelihood type were chosen as this study focused on how crop oriented interventions performed across different landscape positions. Of the eleven fields, five were in upland, three in upper lowlands and three in lower lowlands. A three-factor experiment was set-up in a split-plot design with the factors as landscape position at three levels (upland, upper lowland and lower lowland), manure at two rates ( 0 and $10 \mathrm{t} / \mathrm{ha}$ ) and crop variety (five for maize, three for sorghum, one for millet and one for groundnut). Each site was a complete replicate block which was split into two manure treatments for ease of implementation. 
Demarcations of cropping areas as upland, upper lowland and lower lowland, and the identification of typical corresponding sites were done by farmers during focus group discussions and confirmed by their extension workers. For maize, five open pollinated varieties: ZM 309, ZM 401, local (also known as Gopane by some farmers and Chibhubhani by others), ZM 421 and ZM 521 were assessed. The varieties ZM 309, ZM 401 and the local variety (Gopane) are short duration varieties whereas ZM 421 and ZM 521 are medium duration. Three sorghum varieties commonly grown in the area were evaluated: Gangara, Chibedlani and Chihumani. Gangara is red grained variety that is rarely attacked by birds, and is relatively more drought tolerant. Chibedlani is white grain sorghum with large grain which makes it less susceptible to bird damage than Chihumani. Chihumani is white, small grain variety that is the most preferred variety for food due to its good taste and more appealing colour. The single commonly-grown local variety of millet and that for groundnut (Natal common) were included as per farmers request.

At each of the 11 sites (five upland, three upper lowland and three lower lowland), plots measuring $20 \mathrm{~m} \times 25 \mathrm{~m}$ were sub-divided into twenty plots of $5 \mathrm{~m} \times 5 \mathrm{~m}$. In total, there were 220 plots, that is, 11 fields with 2 manure rates and 10 crop varieties at each field. All fields were ploughed using an ox-drawn mouldboard plough to a depth of about $15 \mathrm{~cm}$. Row spacing of $90 \mathrm{~cm}$ was used for the cereals, with $45 \mathrm{~cm}$ spacing for groundnut and within-row spacing of $30 \mathrm{~cm}$. Manure was applied at planting to the 10 plots in one half (10.5 t/ha on DM basis), banded along the furrows. Seed of groundnut was treated with Thiram 80WP (5 g per 400 seed). Maize, sorghum, millet and groundnut were hand planted. The cropping practices of local farmers were incorporated in the design. Maize is planted when enough rain has fallen to wet the soil to $20 \mathrm{~cm}$ depth. If germination is poor, maize is replanted with every good rain until March. Sorghum is dry planted and sorghum and millet are replanted if rain fails in the first part of the season, but only until the end of December to avoid crop ripening at the end of March when quelea birds (Quelea quelea) are particularly problematic. Before planting, germination of all seed was tested by the Department of Seed Services, Harare, which is accredited by the International Seed Testing Association.

At 2 weeks after emergence, establishment was estimated by counting surviving plants in each plot.
Weeding was done twice, initially using a hoe and later by hand pulling. At harvesting, grain yield was estimated in both seasons and above-ground biomass measured in the 2009/2010 season. Grain samples were oven dried at $60{ }^{\circ} \mathrm{C}$ for $48 \mathrm{~h}$ and all yields are reported at moisture contents of $15 \%$ for maize, $11 \%$ for sorghum and millet and $5 \%$ for groundnut. Daily rainfall was recorded by farmers using rain gauges installed at each experimental field block.

\section{Soil and manure properties}

Before preparing the plots for planting, soils were sampled using an auger to a depth of $15 \mathrm{~cm}$ from three points along the diagonal of each experimental field. Soil and manure samples were air-dried and manure was ground to pass through a $2 \mathrm{~mm}$ sieve prior to analyses. The $\mathrm{pH}$ was measured in $0.01 \mathrm{M}$ $\mathrm{CaCl}_{2}$, organic carbon determined using the Walkley-Black method (Nelson and Sommers 1982), and total phosphorus was determined by the molybdenum-blue method after ashing. Exchangeable potassium was measured in an acidified ammonium acetate extract method using a flame photometer. Texture analysis was done using the hydrometer method with sodium hexametaphosphate solution (calgon) as a dispersion agent as described by van Reeuwijk (2002).

\section{Data analysis}

Data were normalised using a $\arcsin (\operatorname{square}-\operatorname{root}(\mathrm{X})$ ) transformation for crop establishment and $\log _{10}$ transformation for grain yield (McDonald 2009). The statistical model used took into consideration main effects of variety, landscape position and manure and all two way interactions possible as well as the three way interaction. Analysis of variance was done in SAS 9.2 (SAS 2008) using Tukey for post hoc separation of means where interactions were not significant. Crop growth and management combinations that resulted in better yields than using current practices (i.e. cropping one local maize variety, no use of additional nutrients like manure, undefined use of different landscape positions) and suffer less yield reduction during bad seasons (coined as 'best-fit' in this paper), were used to analyse the consequences of certain cropping strategies for household food selfsufficiency. These 'best-fit' options were compared 
with the current management strategies, which entail growing only one maize variety 'local' and three varieties of sorghum in all three landscape positions. Two key assumptions were implicitly made in this evaluation of strategies. The first assumption was that in good years there is sufficient rainfall (close to or above the long-term average) spread evenly throughout the season, resulting in not more than two repeat plantings. Bad years have poorly-distributed rainfall such as a single downpour every month, mid-season droughts often resulting in death of a substantial proportion of the plants. This follows outcomes from focus group discussions with local people. The second assumption was that labour and cropping implements are not limiting basing on evidence from Murungweni et al. (2014) that almost all farmers have access to draught power, most households $(71.8 \%)$ own a plough and there is a network for dealing with labour bottlenecks (e.g. nhimbe) in south eastern Zimbabwe.

\section{Results}

Rainfall patterns

Total rainfall was highly variable between the 11 experimental sites ranging from 376 to $646 \mathrm{~mm}$ within a $100 \mathrm{~km}$ radius of Gonarezhou (Mabalauta subregion) in 2008/2009 and from 410 to $602 \mathrm{~mm}$ in the 2009/2010 season. Despite these total rainfall amounts being close to the long-term average values (491 vs. $476 \mathrm{~mm}$ ), rainfall distribution in the 2008/2009 and the 2009/2010 seasons differed markedly, the latter showing more heavy downpours and longer dry spells (Fig. 3). This caused major differences in establishment and yield of all crops. The effects of rainfall pattern are manifested in the number of times that farmers replant their crop (Fig. 3). All crops were replanted once during 2008/2009 season. By contrast, long dry spells led to repeated crop failure during the 2009/2010 season (Fig. 3). In the 2009/2010 season, sorghum, millet and groundnut were replanted once and maize was replanted twice.

\section{Soil and manure characteristics}

The manure that was used in field experiments contained $520 \mathrm{~g} / \mathrm{kg} \mathrm{DM}$ ash $(\mathrm{SD}=72.5)$. Nutrient content of the $10.5 \mathrm{t} / \mathrm{ha}$ manure applied was $2730 \mathrm{~kg} / \mathrm{ha}$ organic C (SD $=546), 147 \mathrm{~kg} / \mathrm{ha}$ of $\mathrm{N}(\mathrm{SD}=10.5)$, $47 \mathrm{~kg} / \mathrm{ha}$ of $\mathrm{P}(\mathrm{SD}=15.0)$ and $535 \mathrm{~kg} / \mathrm{ha}$ of $\mathrm{K}$ $(\mathrm{SD}=205)$. The soil make-up of the three landscape positions differed in soil texture, upper lowland soils were finer textured than soils from the other landscape positions (Table 1). Their bulk density was relatively lower with a $\mathrm{C}$ and $\mathrm{N}$ content greater than those for the other landscape positions (Table 1).

Maize production

All four factors (season, variety, manure and landscape) had a significant influence on establishment and yield of maize $(P<0.05$, Table 2$)$. However, the effect of variety and landscape on establishment and yield of maize was not independent between seasons as shown by significant interactions $(P<0.05)$ in Table 2. Only manure had independent effects on both establishment and yield. Due to the interaction of factors, short season varieties of maize crop establishment were more successful and yielded better despite nature of season and best when grown in the lower lowlands with manure (Fig. 4). The seasonal differences can be explained better by the within season distribution of rainfall than by the total amount of rainfall. All varieties yielded poorly in the uplands despite the use of additional soil nutrients (manure). However, manure had no overall effect on crop establishment but it increased grain yield $(P<0.05)$ in the lower lowlands in both seasons. There were no differences in maize grain yield between the upper lowland and upland harvests, even though establishment was more successful in the upper lowlands. Despite the poor grain yields recorded in the 2009/2010 season, maize produced more above-ground biomass in the lower and upper lowlands $(P<0.001)$ than that in the uplands (Fig. 5).

\section{Sorghum production}

Contrary to maize, sorghum established more successfully in the 2009/2010 season than in the $2008 / 2009$ season, but yielded more in 2008/2009 than in 2009/2010 (Table 3). Only two factors (landscape position and manure) had a significant influence on crop establishment but all factors significantly influenced yield (Table 3). Differences in sorghum establishment between landscape 
Fig. 3 Rainfall (mm) during the 2008/2009 and 2009/2010 growing seasons at the eleven study sites in the south-east lowveld, Zimbabwe. Dashed arrows (re)planting dates for sorghum, millet and groundnut and closed arrows for maize. Numbers on graphs correspond with the number of the experimental plot in Fig. 2

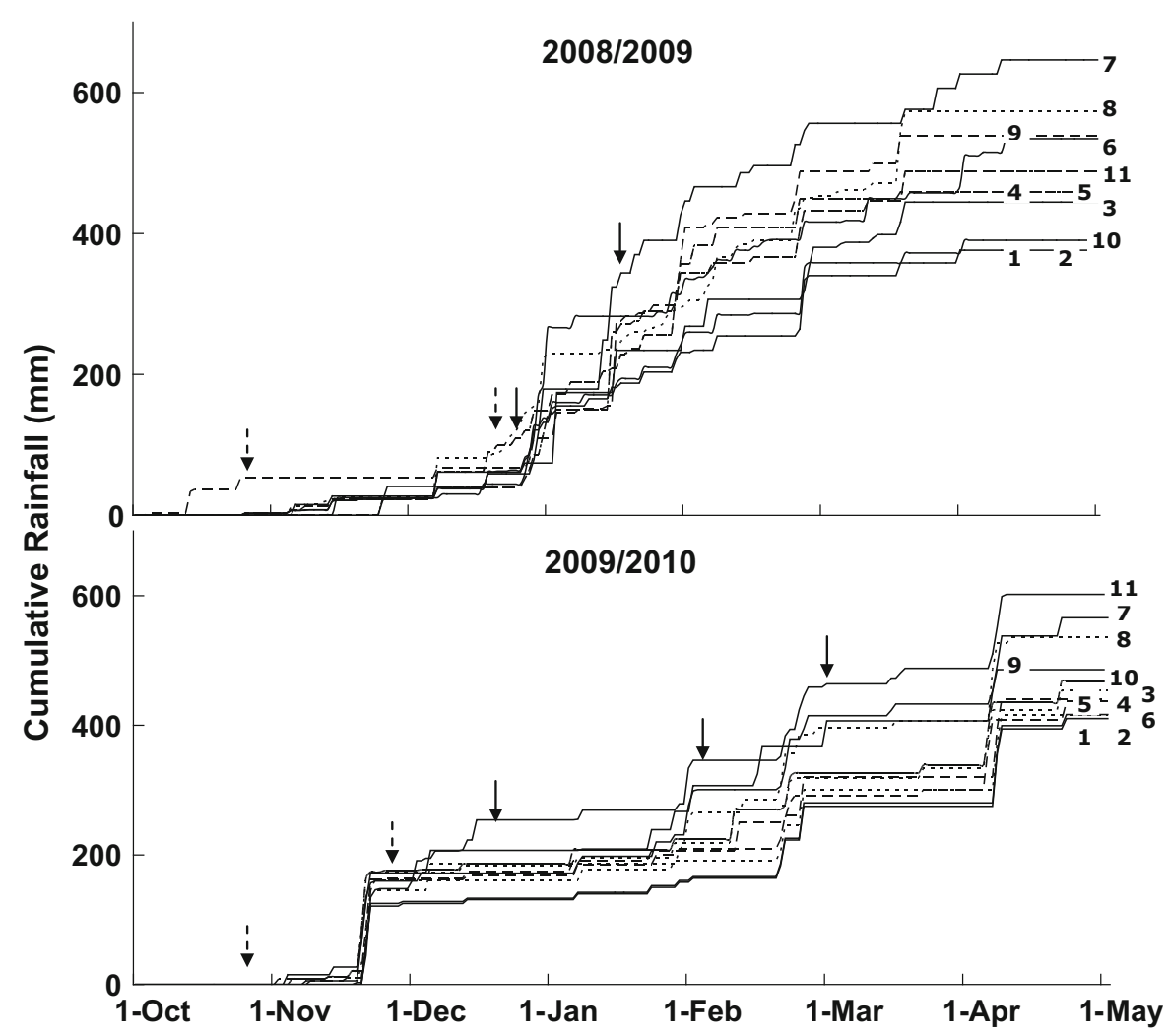

Table 1 Soil physical and chemical characteristics of the three land units (average values of 11 study sites) (standard errors in parentheses) in Sengwe, south eastern Zimbabwe

\begin{tabular}{|c|c|c|c|c|c|c|}
\hline Land unit & & Clay $(\%)$ & Silt $(\%)$ & & Sand $(\%)$ & Bulk density $\left(\mathrm{g} / \mathrm{cm}^{3}\right)$ \\
\hline Uplands & & $20.4(3.6)$ & $19.0(4.1)$ & & $60.6(7.3)$ & $1.51(0.05)$ \\
\hline Upper lowlands & & $25.0(4.7)$ & $29.7(5.3)$ & & $45.3(9.4)$ & $1.31(0.04)$ \\
\hline Lower lowlands & & $12.7(4.7)$ & $18.3(5.3)$ & & $69.0(9.4)$ & $1.41(0.05)$ \\
\hline Land unit & $\mathrm{pH}$ & $\begin{array}{l}\text { Organic carbon } \\
\text { (C) }(\mathrm{g} / \mathrm{kg})\end{array}$ & $\begin{array}{l}\text { Total nitrogen } \\
\text { (N) }(\mathrm{g} / \mathrm{kg})\end{array}$ & $\mathrm{C}: \mathrm{N}$ & $\begin{array}{l}\text { Total phosphorus } \\
\text { (P) }(\mathrm{mg} / \mathrm{kg})\end{array}$ & $\begin{array}{l}\text { Extractable potassium } \\
\text { (K) }(\mathrm{cmol} / \mathrm{kg})\end{array}$ \\
\hline Uplands & $7.1(0.5)$ & $9.0(5)$ & $0.6(0.1)$ & 15 & $555(490)$ & $1.24(0.58)$ \\
\hline Upper lowlands & $6.9(0.1)$ & $18(5)$ & $0.8(0.1)$ & 22.5 & $556(250)$ & $1.98(0.26)$ \\
\hline Lower lowlands & $6.7(0.3)$ & $10(2)$ & $0.6(0.1)$ & 16.7 & $311(124)$ & $1.22(0.26)$ \\
\hline
\end{tabular}

positions were not consistent between seasons as shown by the two significant interactions in Table 3. The inconsistencies were more pronounced where manure was used. However, the influence of manure on consistence of differences between landscape positions disappeared on yield assessments. The positive interaction between landscape position and season resulted in yield differences. Manure had no effect on crop establishment but had a positive interaction with landscape position resulting in increased grain yield in upland fields (Table 3; Fig. 6). The upland crop yielded the most although crop establishment was similar across all three landscape positions. Above-ground biomass of sorghum (Fig. 5) was similar across the three landscape positions but between plots, variation was much smaller in lower lowlands than in the other two landscape positions. 
Table 2 Consequences of season, variety, manure and landscape position on grain yield of maize in a semiarid environment of Sengwe in south eastern Zimbabwe
Within column means under same factor, with different superscripts are different at $P<0.05$

Non-significant interactions are not presented

\begin{tabular}{lll}
\hline Factor & \% Establishment & Grain yield (t/ha) \\
\hline Season & & \\
2008/2009 & $44.4^{\mathrm{a}}$ & $0.91^{\mathrm{a}}$ \\
2009/2010 & $35.6^{\mathrm{b}}$ & $0.23^{\mathrm{b}}$ \\
Variety & & \\
ZM309 & $55.8^{\mathrm{a}}$ & $1.68^{\mathrm{a}}$ \\
ZM401 & $49.0^{\mathrm{b}}$ & $1.13^{\mathrm{b}}$ \\
Local & $41.4^{\mathrm{b}}$ & $1.07^{\mathrm{b}}$ \\
ZM421 & $27.8^{\mathrm{c}}$ & $0.28^{\mathrm{c}}$ \\
ZM521 & $26.0^{\mathrm{c}}$ & $0.30^{\mathrm{c}}$ \\
Manure (at 10.5 t/ha) & & \\
No manure applied & $40.0^{\mathrm{a}}$ & $0.51^{\mathrm{a}}$ \\
Manure applied & $39.9^{\mathrm{a}}$ & $0.63^{\mathrm{b}}$ \\
Landscape & & \\
Lower lowlands & $46.9^{\mathrm{a}}$ & $1.30^{\mathrm{a}}$ \\
Upper lowlands & $32.3^{\mathrm{b}}$ & $0.46^{\mathrm{b}}$ \\
Uplands & $40.5^{\mathrm{a}}$ & $0.20^{\mathrm{b}}$ \\
$P$ values & & \\
Season & 0.05 & 0.0001 \\
Variety & 0.0001 & 0.001 \\
Manure & 0.05 & 0.05 \\
Landscape position & 0.001 & 0.0001 \\
Season $\times$ variety & 0.0001 & 0.001 \\
Season $\times$ landscape position & 0.0001 & 0.05 \\
Variety $\times$ landscape position & 0.05 & 0.0001 \\
\hline & &
\end{tabular}

Millet production

Millet consistently yielded poorly in both seasons irrespective of landscape position or manure treatment. Establishment differed significantly between 2008/2009 and 2009/2010 in upper lowlands (39.7 vs. $17.7 \%$ ) and uplands (69.3 vs. $33.2 \%)$, but was similar in the lower lowlands for the two seasons (66.7-66.9 \%). Manure did not affect establishment or yield. Millet yielded more $(P<0.05)$ in the $2008 / 2009$ season $(0.23 \mathrm{t} / \mathrm{ha})$ than in $2009 / 2010$ (0.09 t/ha). Poor grain harvests were obtained more frequently in the lower lowlands than in the other two landscape positions, particularly so in 2009/2010 (Fig. 7). However, more above-ground biomass was produced in the lower lowlands (Fig. 8). 


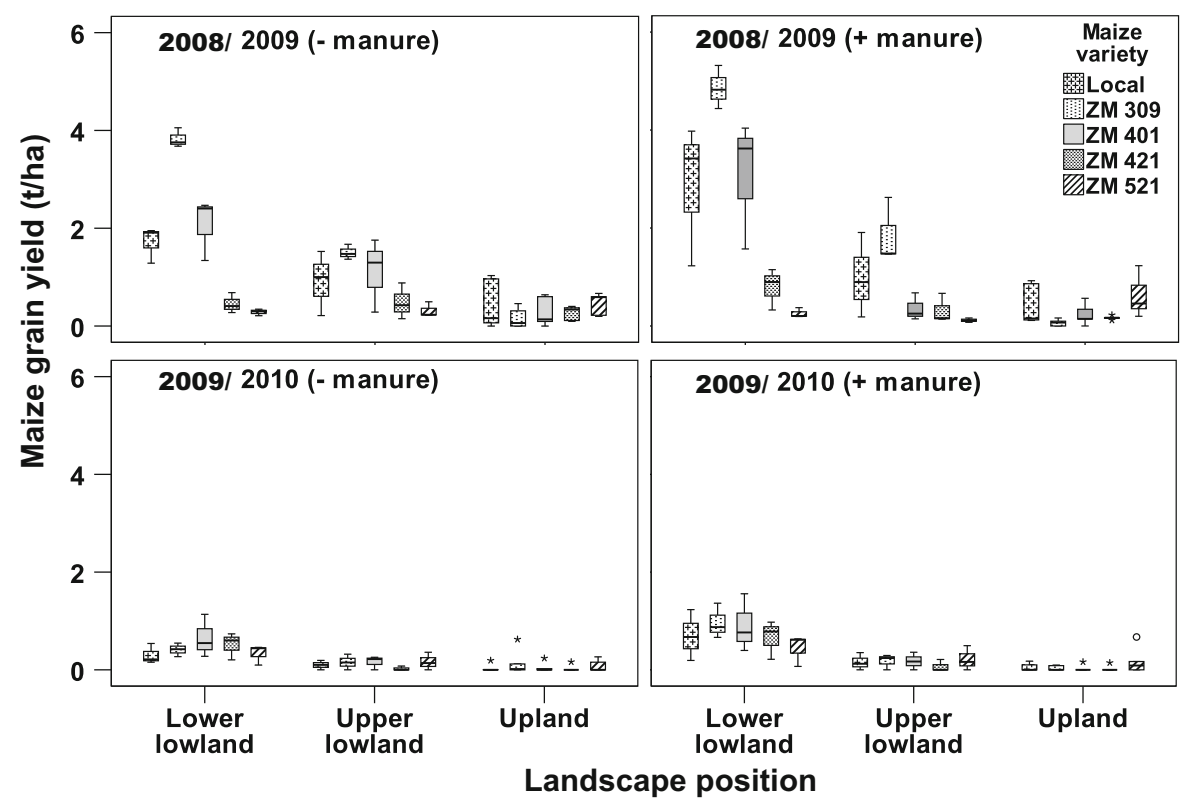

Fig. 4 Grain yield (t/ha) of five maize varieties (local, ZM309, ZM401, ZM421, ZM521), at three landscape positions (lower lowland, upper lowland and upland), with or without application of manure at a rate of $10.5 \mathrm{t} / \mathrm{ha}$, in the 2008/2009 and 2009/2010 growing seasons
Fig. 5 Above-ground residue biomass ( $\mathrm{t} / \mathrm{ha}$ ) of five maize and three sorghum varieties, at three landscape positions (lower lowland, upper lowland and upland), with and without application of manure at a rate of $10.5 \mathrm{t} / \mathrm{ha}$, in the 2009-2010 growing season

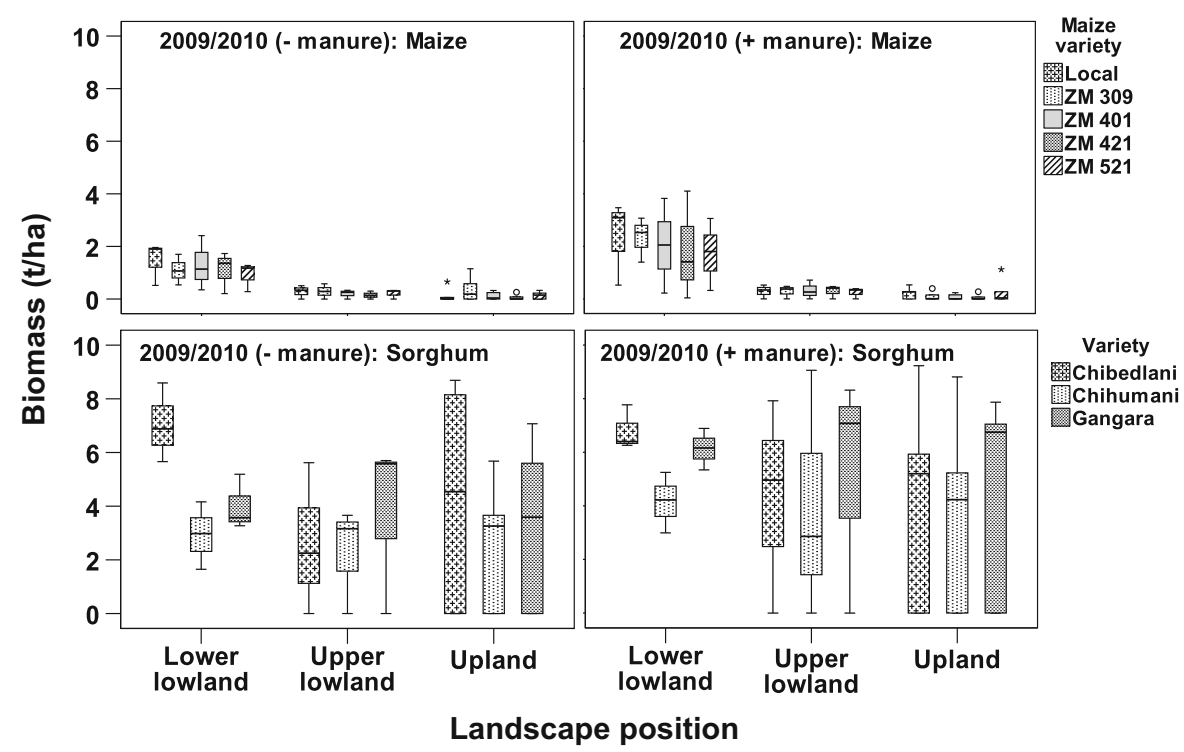

Groundnut production

Groundnut established more successfully $(P<0.05)$ in $2008 / 2009$ than in the $2009 / 2010$ season but grain yields did not differ between the two seasons (Table 4). Application of manure reduced establishment, but no differences in grain yield were observed. Groundnut produced more above-ground biomass in the uplands than in the other two landscape positions (Fig. 7).

Farm-level maximum grain production

Farm-level maximum grain production was estimated using a cropping system that resulted in largest yields 
Table 3 Consequences of season, variety, manure and landscape position on grain yield of sorghum in a semiarid environment of Sengwe in south eastern Zimbabwe

Within column means under same factor, with different superscripts are different at $P<0.05$

Non-significant interactions are not presented

Fig. 6 Grain yield (t/ha) of three sorghum varieties, at three landscape positions (lower lowland, upper lowland and upland), with and without application of manure at a rate of $10.5 \mathrm{t} / \mathrm{ha}$ in the 2008/2009 and 2009/2010 growing seasons

\begin{tabular}{lll}
\hline Factor & $\%$ Establishment & Grain yield (t/ha) \\
\hline Season & & \\
$2008 / 2009$ & $64.3^{\mathrm{b}}$ & $1.82^{\mathrm{a}}$ \\
$2009 / 2010$ & $76.5^{\mathrm{a}}$ & $0.42^{\mathrm{b}}$ \\
Variety & & \\
Gangara & $71.3^{\mathrm{a}}$ & $1.45^{\mathrm{a}}$ \\
Chibedlani & $71.1^{\mathrm{a}}$ & $0.92^{\mathrm{b}}$ \\
Chihumani & $68.8^{\mathrm{a}}$ & $0.98^{\mathrm{b}}$ \\
Manure (at 10.5 t/ha) & & \\
No manure applied & $69.6^{\mathrm{a}}$ & $0.92^{\mathrm{b}}$ \\
Manure applied & $71.2^{\mathrm{a}}$ & $1.31^{\mathrm{a}}$ \\
Landscape & & \\
Lower lowlands & $84.9^{\mathrm{a}}$ & $1.15^{\mathrm{b}}$ \\
Upper lowlands & $55.5^{\mathrm{b}}$ & $0.63^{\mathrm{b}}$ \\
Uplands & $72.0^{\mathrm{a}}$ & $1.39^{\mathrm{a}}$ \\
$P$ values & & \\
Season & $\mathrm{ns}$ & 0.0001 \\
Variety & $\mathrm{ns}$ & 0.0001 \\
Manure & 0.01 & 0.01 \\
Landscape position & 0.0001 & 0.0001 \\
Season $\times$ landscape position & 0.01 & 0.001 \\
Variety $\times$ season & $\mathrm{ns}$ & 0.05 \\
Manure $\times$ season & 0.01 & 0.01 \\
Landscape position $\times$ manure & & \\
\hline & & \\
\hline
\end{tabular}

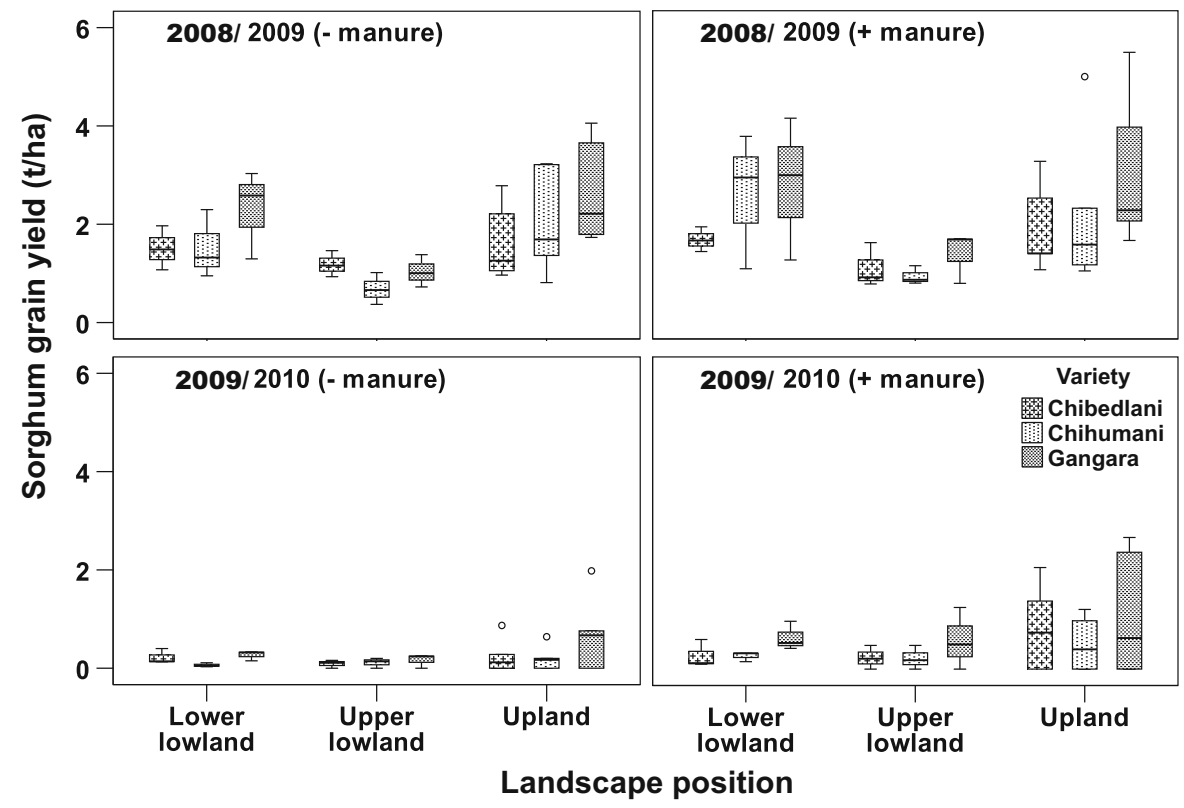


Fig. 7 Grain yield (t/ha) of two millet and two groundnut varieties, at three landscape positions (lower lowland, upper lowland and upland), with or without application of manure at a rate of $10.5 \mathrm{t} / \mathrm{ha}$ in the 2008/2009 and 2009/2010 growing seasons

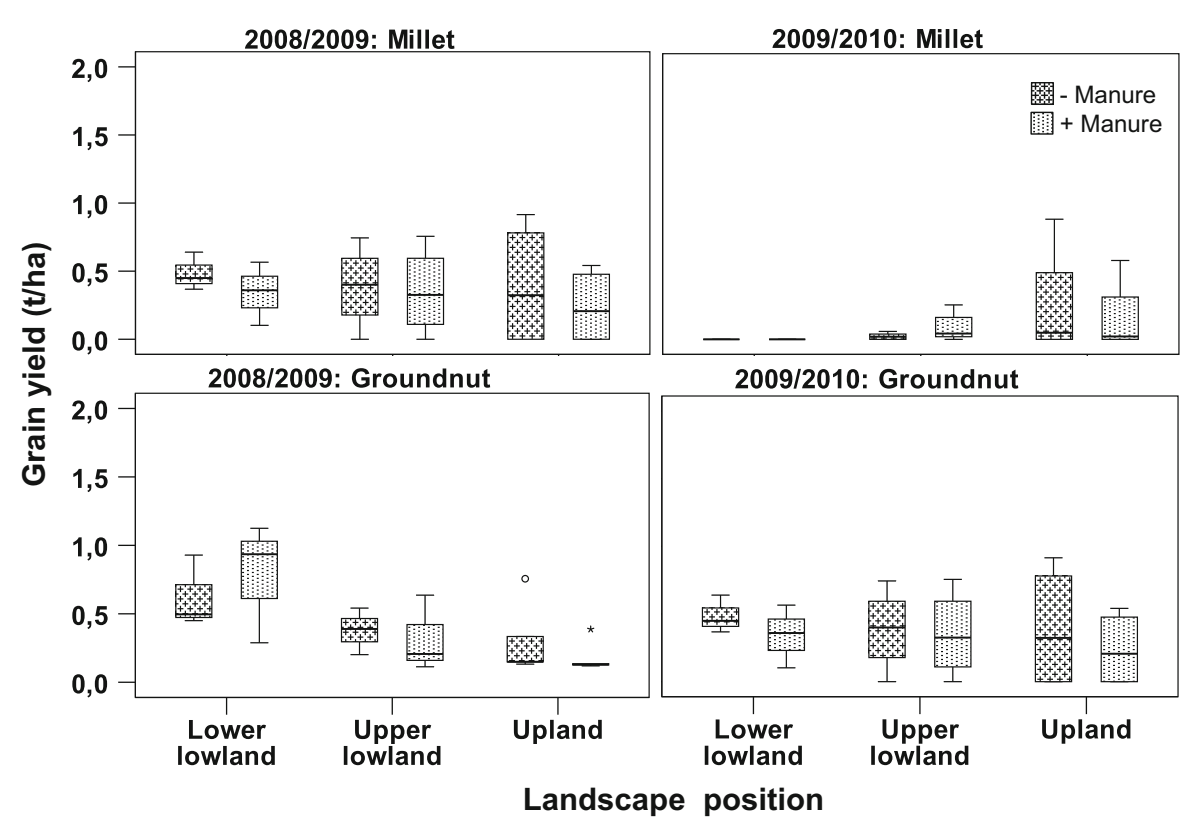

Fig. 8 Above-ground residue biomass ( $\mathrm{t} / \mathrm{ha}$ ) of millet and groundnut, at three landscape positions (lower lowland, upper lowland and upland), with or without application of manure at a rate of $10.5 \mathrm{t} / \mathrm{ha}$ in the 2009-2010 growing season

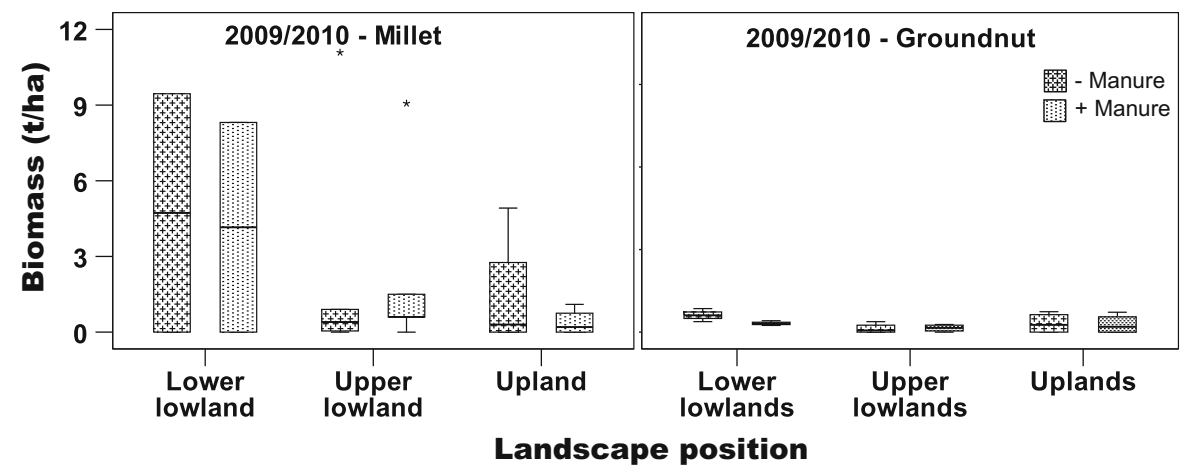

for each landscape position. Sorghum did best with manure in uplands. Since the three varieties have good yields, cropping all three varieties would help in spreading risk of loss by birds. Maize was best with manure in lower lowlands and without manure in upper lowlands when cropping short season varieties like Local, ZM 401 and ZM 309. Millet has potential as observed from the biomass produced but grain yield losses to birds are substantial. Unless appropriate procedures are put into place either to control birds or to protect millet from birds, millet production will remain restricted. Sorghum and maize were chosen as 'best-fit' crop options and assessed with and without manure at farm-level for their potential impacts on household food production (Table 5). Changing the farming systems from current practice to the practice that maximises production while reducing risk of crop failure, would result in an increased yield of 2.54 tons per farm in seasons similar to $2008 / 2009$ or an increased yield of 1.62 tons per farm in seasons similar to $2009 / 2010$.

\section{Discussion}

Low lying areas tend to have less risk of crop failure during a drought but can be vulnerable to flooding as experienced in 1999. Research results showed that farmers in semi-arid areas can reduce risk of total crop failure by making a clever use of both the low lying 
Table 4 Consequences of season, variety, manure and landscape position of grain yield of groundnut in a semi-arid environment of Sengwe in south eastern Zimbabwe

\begin{tabular}{lll}
\hline Factor & \% Establishment & Grain yield (t/ha) \\
\hline Season & & \\
$2008 / 2009$ & $58.1^{\mathrm{a}}$ & $0.69^{\mathrm{a}}$ \\
$2009 / 2010$ & $51.0^{\mathrm{a}}$ & $0.40^{\mathrm{b}}$ \\
Manure (at 10.5 t/ha) & & \\
No manure applied & $60.9^{\mathrm{a}}$ & $0.58^{\mathrm{a}}$ \\
Manure applied & $48.3^{\mathrm{b}}$ & $0.51^{\mathrm{b}}$ \\
Landscape & & \\
Lower lowlands & $61.3^{\mathrm{a}}$ & $0.85^{\mathrm{a}}$ \\
Upper lowlands & $47.6^{\mathrm{a}}$ & $0.44^{\mathrm{b}}$ \\
Uplands & $54.7^{\mathrm{a}}$ & $0.42^{\mathrm{b}}$ \\
$P$ values & & \\
Season & 0.0005 & 0.0152 \\
\hline
\end{tabular}

Within column means under same factor, with different superscripts are different at $P<0.05$

Non-significant interactions are not presented

and the upland areas depending on crops of their interest. In south eastern Zimbabwe, high variability in rainfall (Fig. 3) and in soil nutrients (Table 1) across landscape positions resulted in a temporal and spatial mosaic of crop yield responses across the landscape positions that resulted in formulation of best-fit strategies that farmers can exploit in order to reduce total crop failure across seasons. Farmers can increase their yields substantially by managing this variability; even if they lack access to the lower lowlands i.e. flood plains (Table 5).

In both poor and good rainfall seasons, the best-fit strategies resulted in higher production than the current practice of diversification within the same field (Table 5). During focus group discussions, farmers described how they would characterize a good year and a bad year for cropping. After the experimental research was concluded we shared results with the farmers and evaluated the 2 years in which the experiment was conducted: the farmers indeed assessed and described the 2 years as representative of a good year (2008/2009) and a bad year (2009/2010). The experimental years therefore span the type of rainfall range that farmers experience over the years. For those farmers with access to all three landscape positions described, best-fit strategies could be the method of choice. The win in terms of land needed for sufficient production decreased substantially, thereby stating something about the robustness as well. The crop yield response to manure differed strongly between landscape position and year (Figs. 4, $5,6,7)$, resulting in specific strategies of when and where to use the limited amount of manure available (Table 5). Soil fertility differences are important for farmers when they make decisions on crop allocation, and these differences are amplified by farmers' management in many regions, leading to preferred plots for the best crops (Samake et al. 2005; Tittonell et al. 2006, 2007; Wortmann and Kaizzi 1998). The use of manure is almost always beneficial for crops (Affholder 1995; de Rouw 2004; Zingore et al. 2008). Manure is known to improve production often in good rainfall areas. In drier regions use of manure is restricted by the historical perception that manure can exacerbate negative effects of heat on crop resulting from fact that ammonium in the manure can burn the crop if manure is placed in the planting hole. Our results clearly show the benefits of adding manure on crop growth and yield if manure is banded alongside the planting row.

The effort required to apply 10 tons of manure per hectare appears disproportionate to the small increase in grain yield achieved during a bad year. However, even a relatively small increase in yield in a bad year is important for the food security of these farming households, taking into account their isolation and poor market connections. The production from 2 ha can feed a standard family of 6 persons for a whole year, yet without manure use 4 ha would be required (Table 5). The labour saved by cropping only 2 ha can compensate for the effort used to apply the manure available. In north-west Zimbabwe (Masikati 2011) found that possible manure application rates considering the number of animals owned to be 0.4 (for the poor), 1.9 (for the average) and $4.4 \mathrm{t} / \mathrm{ha}$ (for the betteroff). In these higher rainfall areas farmers often concentrate application of manure to small fields within their farms at rates of 10-20 t/ha (Rusinamhodzi et al. 2013). Rates above 5 t/ha are possible in our study area in south eastern Zimbabwe because of the large cattle ownership (which is substantially larger than in north western Zimbabwe). Crop farmers can use the manure of their own cattle, but also potentially can access manure produced by the cattle of the livestock-based farm type. 
Table 5 Farm-level grain production potential of crop farmers in Sengwe in south eastern Zimbabwe taking into account the average areas of fields in each landscape position available to each household

\begin{tabular}{|c|c|c|c|c|c|c|}
\hline Year & Landscape position & Crop & Manure & $\begin{array}{l}\text { Area } \\
\text { cropped (ha) }\end{array}$ & $\begin{array}{l}\text { Yield } \\
(\mathrm{t} / \mathrm{ha})\end{array}$ & $\begin{array}{l}\text { Total } \\
\text { harvest (ton) }\end{array}$ \\
\hline \multicolumn{7}{|l|}{ Present strategy } \\
\hline \multirow[t]{3}{*}{ Good } & Upland & Sorghum/maize & No & 2.80 & 1.90 & 5.32 \\
\hline & Upper lowland & Maize/sorghum & No & 1.40 & 1.18 & 1.65 \\
\hline & Lower lowland & Maize & No & 0.90 & 2.54 & 2.29 \\
\hline Total farm-level production $2008 / 2009$ & & & & & & 9.26 \\
\hline \multirow[t]{3}{*}{$\mathrm{Bad}$} & Upland & Sorghum & No & 2.80 & 0.38 & 1.06 \\
\hline & Lower lowland & Maize & No & 1.40 & 0.14 & 0.20 \\
\hline & Lower lowland & Maize & No & 0.90 & 0.46 & 0.41 \\
\hline Total farm-level production $2009 / 2010$ & & & & & & 1.67 \\
\hline \multicolumn{7}{|l|}{ 'Best-fit' strategy } \\
\hline \multirow[t]{3}{*}{ Good } & Upland & Sorghum & Yes & 2.80 & 2.46 & 6.89 \\
\hline & Upper lowland & Maize & No & 1.40 & 1.18 & 1.65 \\
\hline & Lower lowland & Maize & Yes & 0.90 & 3.60 & 3.24 \\
\hline Total farm-level production 2008/2009 & & & & & & 11.8 \\
\hline \multirow[t]{3}{*}{ Bad } & Upland & Sorghum & Yes & 2.80 & 0.83 & 2.32 \\
\hline & Lower lowland & Maize & No & 1.40 & 0.14 & 0.20 \\
\hline & Lower lowland & Maize & Yes & 0.90 & 0.86 & 0.77 \\
\hline Total farm-level production $2009 / 2010$ & & & & & & 3.29 \\
\hline
\end{tabular}

Mean land size per household from survey data (Murungweni 2011) were used in combination with yield data from field crop experiments carried out over two seasons (2008/2009 and 2009/2010)

The results of this study suggests that short season maize varieties like ZM 309, ZM 401 and the locally grown Gopane grow best in this semi-arid climate and are also superior is in lower-lying areas where problems of water availability are less acute (Tables 2 , 3 ). Repeated planting regimes due to erratic rains are a common feature of semi-arid areas (Milgroom and Giller 2013), but can be costly when using varieties with poor establishment. For farmers interested to invest in crop production, the options for adaptation consists of crop types, crop varieties, use of different physiographic positions in the landscape, and application of manure. By virtue of the experimental set-up, combinations of these four factors led to 'best-fit' options, which would not have been possible when studied in isolation. Calculations of alternative production scenarios at farm level clearly show that a combination of manure and landscape position works best for maize in lower lowlands and for sorghum in uplands as an example (Table 5). To realize the potential, farmers have to be willing and able to invest in labour, particularly when it comes to replanting, to store and re-use manure, to handle seed systems that cover a mix of crops and crop varieties and to deal with trade-offs.

To make optimal use of the land use decisions suggested in Table 5, farmers would need access to seasonal climate forecasts. Other factors not covered in this study also determine crop choice. In terms of taste for example, farmers maize above sorghum, but in terms of reducing risk due to drought, they grow sorghum and mix varieties to reduce risk of loss by birds. Farmers make the same considerations when selecting which crop variety to plant. For example, farmers in the study area prefer varieties Chihumani and Chibedlani compared with Gangara, because they taste better and have a more appealing grain flour colour (white). However, Gangara (red sorghum) is relatively more tolerant to drought, has greater persistence and does not suffer as much from losses to birds. From these observations it is clear that yields are not the only factor to take into account when promoting a crop or crop variety. Social organisation is also important for managing risk and can affect crop 
choice. For example, to reduce losses by quelea birds, farmers hold a cultural event every year about 1 week before young birds fly, the whole community goes out to the rivers to harvest birds from their nests. Later in the season farmers have to guard fields until the crop is harvested.

Semi-arid environments are prone to hazards that affect agriculture (Monteith 1991; Rockstrom 2000). Droughts, floods, and the presence of quelea birds are all common in south eastern Zimbabwe. Drought can manifest itself as an absolute lack of rainfall in a cropping year, but it can do similar damage to crop development when occurring as a series of dry spells with intermittent heavy downpours. This was the case during the second year of our study, but is hidden from view when comparing the rainfall totals for both seasons, which are more or less similar. Next to this temporal aspect, spatial variation in rainfall over relatively short distances is also substantial (Fig. 3).

People in semi-arid areas are inherently vulnerable to hazards such as drought, and in need of risk management strategies. The choices include: refrain from farming in the first place and instead rely on other sources of income including remittances; migrate to better-endowed areas or urban areas; or make agriculture more "climate smart" (Campbell et al. 2014) though use of genotypic, environmental and management variation in order to get the best out of relatively harsh and poorly predictable situations.

Against the backdrop of the proven increasing incidence of cropping years that are too wet, too dry, or average but with major dry spells (Lean and Rind 2009; Rind et al. 1989), it is important to make clever use of the diversity offered by crops and land. Resource availability, such as lack of manure, seed of specific crop varieties, labour and access to lower lowlands can limit the success of strategies proposed in this study. Snapp et al. (2002) concluded that the adoption rates for 'best bet' legume technologies are affected by poor markets. However, as the farmers declared that their goal is to harvest at least some grain they are likely to adopt technologies that reduce the risk of crop loss. Different crops and crop varieties respond differently to hazards. The 'best-fits' implemented at farm level result in substantial yield increases from 1.62 to 2.54 tons per farm where land is used most effectively (Table 5). Similarly, Gandah et al. (2003) and Stroosnijder and van Rheenen (2001) found that physiographic differences at farm and village level used for diverse agricultural production in West African Sahel. Whilst there is less risk of drought in low-lying areas that usually produce more than upland fields, they are also more prone to flooding. Our study quantifies how farmers in semiarid areas can use different landscape positions to reduce risk by balancing cropping according to the differing degrees of tolerance of crops and crop varieties to rainfall variability. This approach is key to making the farm-level production more climate-smart.

Acknowledgments This research was funded by the International Research and Education Fund (INREF) of Wageningen University through the Competing Claims on Natural Resources programme (www.competingclaims.nl). We also thank Robert Mukosa, Mazvita Murwira, Armwell Shumba, Mr. Chikwari and staff of Grasslands Research Station for assistance.

Open Access This article is distributed under the terms of the Creative Commons Attribution 4.0 International License (http:// creativecommons.org/licenses/by/4.0/), which permits unrestricted use, distribution, and reproduction in any medium, provided you give appropriate credit to the original author(s) and the source, provide a link to the Creative Commons license, and indicate if changes were made.

\section{References}

Affholder F (1995) Effect of organic-matter input on the waterbalance and yield of millet under tropical dryland condition. Field Crops Res 41:109-121

Batisani N, Yarnal B (2010) Rainfall variability and trends in semi-arid Botswana: implications for climate change adaptation policy. Appl Geogr 30:483-489

Campbell BM, Thornton P, Zougmoré R, van Asten P, Lipper L (2014) Sustainable intensification: What is its role in climate smart agriculture? Curr Opin Environ Sustain 8:39-43. doi:10.1016/j.cosust.2014.07.002

Cooper PJM, Dimes J, Rao KPC, Shapiro B, Shiferaw B, Twomlow S (2008) Coping better with current climatic variability in the rain-fed farming systems of sub-Saharan Africa: An essential first step in adapting to future climate change? Agric Ecosyst Environ 126:24-35. doi:10.1016/j. agee.2008.01.007

CSO (2002) Provincial profile Masvingo. Central Census Office, Census 2002. Central Statistics Office, Harare

Cumming D, Biggs H, Kock M, Shongwe N, Osofsky S (2007) The AHEAD (Animal Health for Environment And Development)_Great Limpopo Transfrontier Conservation Area (GLTFCA) Programme: key questions and conceptual framework revisited. In: The AHEAD (Animal Health for Environment and Development)-Great Limpopo Transfrontier Conservation Area (GLTFCA) Programme: key questions and conceptual framework revisited: http://wcs-ahead.org/workinggrps_limpopo.html 
de Rouw A (2004) Improving yields and reducing risks in pearl millet farming in the African Sahel. Agric Syst 81:73-93. doi:10.1016/j.agsy.2003.09.002

Debaeke P, Aboudrare A (2004) Adaptation of crop management to water-limited environments. Eur $\mathrm{J}$ Agron 21:433-446. doi:10.1016/j.eja.2004.07.006

Dixon J, Gulliver A, Gibbon D (2001) Global farming systems: challenges and priorities to 2030. FAO, Publishing and Media Service, Italy, pp 18-24

Dzingirai V (2003) The new scramble for the African countryside. Dev Change 34(2):243-264

Eldridge C (2002) Why was there no famine following the 1992 Southern African Drought? IDS Bull 33:79-87. doi:10. 1111/j.1759-5436.2002.tb00047.x

Gandah M, Brouwer J, Hiernaux P, Van Duivenbooden N (2003) Fertility management and landscape position: farmers' use of nutrient sources in western Niger and possible improvements. Nutr Cycl Agroecosyst 67:55-66

Giller KE, Murwira MS, Dhliwayo DKC, Mafongoya PL, Mpepereki S (2011) Soyabeans and sustainable agriculture in southern Africa. Int J Agric Sustain 9:50-58. doi:10. 3763/ijas.2010.0548

Lean JL, Rind DH (2009) How will Earth's surface temperature change in future decades? Geophys Res Lett 36:L15708. doi: $10.1029 / 2009 \mathrm{gl} 1038932$

Masikati P (2011) Improving the water productivity of integrated crop-livestock systems in the semi-arid tropics of Zimbabwe: an ex-ante analysis using simulation modeling. $\mathrm{PhD}$ thesis, University of Bonn, Bonn, Germany

McDonald JH (2009) Handbook of biological statistics, 2nd edn. Sparky House Publishing, Baltimore

Milgroom J, Giller KE (2013) Courting the rain: rethinking seasonality and adaptation to recurrent drought in semiarid southern Africa. Agric Syst 118:91-104. doi:10.1016/ j.agsy.2013.03.002

Monteith JL (1991) Weather and water in the Sudano-Sahelian zone. In: Sivakumar MVK, Wallace JS, Renard C, Giroux C (eds) Soil water balance in the Sudano-Sahelian zone. Proceedings of the international workshop, Niamey, Niger, February 1991, IAHS Publication no. 199, IAHS Press, Institute of Hydrology, Wallingford, pp 11-30

Murungweni C (2011) Vulnerability and resilience of competing land-based livelihoods in south eastern Zimbabwe. $\mathrm{PhD}$ thesis, Wageningen University, Wageningen, The Netherlands

Murungweni C, van Wijk MT, Giller KE, Andersson JA, Smaling EMA (2014) Adaptive livelihood strategies employed by farmers to close the food gap in semi-arid south eastern Zimbabwe. Food Secur 6:313-326. doi:10.1007/ s12571-014-0348-2

Nelson DW, Sommers LE (1982) Total carbon, organic carbon and organic matter. In: Page AL, Miller RH, Keeney DR (eds) Methods of soil analysis. American Society of Agronomy, Madison

Noy-Meir I (1973) Desert ecosystems: environment and producers. Annu Rev Ecol Syst 4:25-51. doi:10.1146/ annurev.es.04.110173.000325

Rind D, Goldberg R, Ruedy R (1989) Change in climate variability in the 21st-century. Clim Change 14:5-37
Rockstrom J (2000) Water resources management in smallholder farms in Eastern and Southern Africa: an overview. Phys Chem Earth B Hydrol Oceans Atmos 25:275-283

Rusinamhodzi L, Corbeels M, Zingore S, Nyamangara J, Giller KE (2013) Pushing the envelope? Maize production intensification and the role of cattle manure in recovery of degraded soils in smallholder farming areas of Zimbabwe. Field Crops Res 147:40-53

Samake O, Smaling EMA, Kropff MJ, Stomph TJ, Kodio A (2005) Effects of cultivation practices on spatial variation of soil fertility and millet yields in the Sahel of Mali. Agric Ecosyst Environ 109:335-345. doi:10.1016/j.agee.2005. 02.024

SAS (2008) SAS/STAT ${ }^{\circledR} 9.2$ user's guide. SAS Institute Inc., Cary

Snapp SS, Rohrbach DD, Simtowe F, Freeman HA (2002) Sustainable soil management options for Malawi: Can smallholder farmers grow more legumes? Agric Ecosyst Environ 91:159-174

Snyder KA, Tartowski SL (2006) Multi-scale temporal variation in water availability: implications for vegetation dynamics in arid and semi-arid ecosystems. $\mathrm{J}$ Arid Environ 65:219-234

Spenceley A (2008) Requirements for sustainable nature-based tourism in transfrontier conservation areas: a southern African Delphi consultation. Tour Geogr 10:285-311. doi:10.1080/14616680802236295

Stroosnijder L, van Rheenen T (eds) (2001) Agro-silvo-pastoral land use in Sahelian villages. Catena Verlag, Reiskirchen

Tittonell P, Leffelaar PA, Vanlauwe B, van Wijk MT, Giller KE (2006) Exploring diversity of crop and soil management within smallholder African farms: a dynamic model for simulation of $\mathrm{N}$ balances and use efficiencies at field scale. Agric Syst 91:71-101

Tittonell P, Vanlauwe B, de Ridder N, Giller KE (2007) Heterogeneity of crop productivity and resource use efficiency within smallholder Kenyan farms: Soil fertility gradients or management intensity gradients? Agric Syst 94:376-390

UNDP/UNSO (1997) Aridity zones and dryland populations: an assessment of population levels in the world's drylands with particular reference to Africa. UNDP Office to Combat Desertification and Drought (UNSO), New York

UNEP (2010) “Africa Water Atlas". Division of Early Warning and Assessment (DEWA). United Nations Environment Programme (UNEP), Nairobi

van Reeuwijk LP (2002) Procedures for soil analysis (technical paper 9). International Soil Reference and Information Centre (ISRIC), Wageningen

Wortmann CS, Kaizzi CK (1998) Nutrient balances and expected effects of alternative practices in farming systems of Uganda. Agric Ecosyst Environ 71:115-129

Zingore S, Delve RJ, Nyamangara J, Giller KE (2008) Multiple benefits of manure: the key to maintenance of soil fertility and restoration of depleted sandy soils on African smallholder farms. Nutr Cycl Agroecosyst 80:267-282. doi:10. 1007/s10705-007-9142-2 